\title{
No fitness costs are induced by Spiroplasma infections of Aphis citricidus reared on two different host plants
}

\author{
A. S. Guidolin ${ }^{a *}$ (D) and F. L. Cônsoli ${ }^{a}$ \\ ${ }^{a}$ Laboratório de Interações em Insetos, Departamento de Entomologia e Acarologia, Escola Superior de Agricultura "Luiz \\ de Queiroz" - ESALQ, Univerisdade de São Paulo - USP, Av. Pádua Dias, 11, CEP 13418-900, Piracicaba, SP, Brasil \\ *e-mail: alinesguidolin@gmail.com
}

Received: May 28, 2018 - Accepted: December 21, 2018 - Distributed: May 31, 2020

(With 1 figure)

\begin{abstract}
Aphids can harbor several secondary symbionts that alter important aphid-related ecological traits, such as defense against natural enemies, heat tolerance and host plant utilization. One of these secondary symbionts, Spiroplasma, is well known in Drosophila as a sex modulator and by interacting with the host immune system. However, little is known on the effects of Spiroplasma on aphids, such as its influence on the host immune defense against fungi and on host plant utilization. Aphid infections by Spiroplasma are known to be low and few aphid species were reported to be infected with this secondary symbiont, however aphids belonging to the genus Aphis in neotropical regions show high infection rates by Spiroplasma. Thus, we investigated the association of Spiroplasma with the tropical aphid Aphis citricidus through comparative biology experiments on two host plants with different nutritional value to the aphid. We demonstrate Spiroplasma induced no significant fitness costs to A. citricidus on either host plant as no changes in the fitness traits we assessed were observed. Spiroplasma infection only induced sutle changes on host longevity and fecundity. Therefore, we concluded Spiroplasma established a neutral interaction with A. citricidus under the selection pressure we tested, and argue on stress conditions that could better demonstrate the role of Spiroplasma in A. citricidus bioecology and associated costs involved.
\end{abstract}

Keywords: aphid-symbionts interactions, comparative biology, host plant suitability, nutritional ecology.

\section{Custo adaptativo induzido por Spiroplasma em Aphis citricidus em duas plantas hospedeiras}

\section{Resumo}

Pulgões podem abrigar vários simbiontes secundários que alteram características ecológicas importantes, como defesa contra inimigos naturais, tolerância ao calor e utilização da planta hospedeira. Um desses simbiontes secundários, Spiroplasma, é estudado em Drosophila por alterar a razão sexual e interagir com o sistema imunológico do hospedeiro. No entanto, pouco se sabe sobre os efeitos do Spiroplasma em pulgões, como sua influência na defesa contra fungos entomopatogénicos ou na utilização da planta hospedeira, por exemplo. Spiroplasma foi identificado em poucas espécies de pulgão e geralmente em baixa densidade, contudo pulgões pertencentes ao gênero Aphis em regiões neotropicais apresentam altas taxas de infecção por Spiroplasma. Assim, investigamos a associação entre Spiroplasma e o pulgão neotropical Aphis citricidus por meio de biologia comparativa em duas plantas hospedeiras com diferentes valores nutricionais para o pulgão. Spiroplasma não causou custo adaptativo significativo para $A$. citricidus em ambas planta hospedeira. A infecção por Spiroplasma induziu apenas pequenas mudanças na longevidade e fecundidade do hospedeiro. Portanto, concluímos que Spiroplasma estabeleceu uma interação neutra com A. citricidus sob ausência de pressão de seleção. Entretanto, discutimos sobre condições de estresse que possam demonstrar o papel de Spiroplasma na bioecologia de $A$. citricidus e os possíveis custos envolvidos.

Palavras chave: interação pulgão-simbionte, biologia comparada, planta hospedeira, ecologia nutricional.

\section{Introduction}

Aphids are associated with many bacterial symbionts, with the obligate symbiont Buchnera aphidicola supplementing the host diet with essential amino acids and vitamins (Buchner, 1965; Douglas, 1998; Hansen and Moran, 2014), and a diversity of secondary symbionts influencing several ecological traits (Moran, 2007; Oliver et al., 2005; Burke and Moran, 2011; Simon et al., 2011; Ferrari et al., 2012; Łukasik et al., 2013a). 
The secondary symbionts so far identified infecting aphids are Arsenophonus, Hamiltonella defensa, Regiella insecticola, Rickettsia, Rickettisiella viridis, Serratia symbiotica, Spiroplasma, Wolbachia and the X-type symbiont. These bacteria may produce phenotypic responses ranging from defense against natural enemies to host plant use (Su et al., 2013; Sugio et al., 2015). For example $H$. defensa, S. symbiotica and $R$. viridis are linked to resistance to macroorganisms (Oliver et al., 2010; Tsuchida et al., 2014), while $R$. insecticola, $R$. viridis, Rickettsia, Spiroplasma and X-type are associated with protection against microorganisms (Ferrari et al., 2001; Łukasik et al., 2013b; Tsuchida et al., 2014; Heyworth and Ferrari, 2015). Wolbachia is known to confer protection against viruses in Drosophila and mosquito, but the role of this bacterium in aphids remains to be explored (Teixeira et al., 2008; Augustinos et al., 2011; Moreira et al., 2009). Besides their defensive role in associated aphids, R. insecticola, S. symbiotica and X-type were also linked with tolerance to heat stress (Montllor et al., 2002; Russell and Moran, 2006; Heyworth and Ferrari, 2015), Spiroplasma, Arsenophonus and Wolbachia with reproductive alterations (Bourtzis and Miller, 2006), and R. insecticola and Arsenophonus with host plant use (Leonardo and Muiru, 2003; Ferrari et al., 2007).

Spiroplasma is a particular interesting genus of bacteria since its members may be associated as ecto and endocytobionts with a variety of plants and arthropods (Anbutsu and Fukatsu, 2011). Moreover, all strains of the genus Spiroplasma are obligatorily associated with insects in some part of their life, either as commensals, pathogens or mutualists (Gasparich, 2002). Spiroplasma are long known as sex ratio distorters in Drosophila species (Ebbert, 1991), and to participate in host defense against nematode and parasitic wasps in Drosophila (Jaenike et al., 2010; Xie et al., 2010).

In aphids, Spiroplasma infections were first reported in A. pisum in 2001 (Fukatsu et al., 2001), and a diversity of aphid phenotypes have been described since then in association with this symbiont. Spiroplasma were reported to reduce fecundity and longevity (Fukatsu et al., 2001; Simon et al., 2011), induce 'male-killing' in the sexual generation (Simon et al., 2011), confer protection against fungi in A. pisum (Eukasik et al., 2012), and to broaden host plant range in aphids (Tsuchida et al., 2004). However, symbiont-induced phenotypes are usually context-dependent, being affected by the symbiont strain, aphid species/clone, host plant, biogeography and abiotic factors (Montllor et al., 2002; Leonardo and Muiru, 2003; Brady and White, 2013; Russell et al., 2013).

Host plant and biogeography are the two least recognized factors that influence symbiont diversity and distribution (McLean et al., 2011), and data on biogeography have been inconsistent, mainly due to unbalanced research efforts focusing in few aphids species constrained to a narrow global range (Tsuchida et al., 2002; Brady et al., 2014; Forister et al., 2015; Zytynska and Weisser, 2016). Spiroplasma has been rarely investigate in South America, although there are indications it may be more prevalent in tropical areas (Zytynska and Weisser, 2016). Indeed, there are very few studies on aphid species with a narrow host range and/or on tropical areas.

Aphis citricidus is a common aphid in tropical areas. Its diet breath is restricted to Citrus plants and a few related species, and acquired economic pest status by vectoring the citrus tristeza virus (CTV) to citrus plants (Halbert and Brown, 1996; Halbert et al., 2004). Although there are few studies on secondary symbiont diversity associated with aphids in tropical areas, our previous investigations on $A$. citricidus association with microbial secondary symbionts indicated Spiroplasma as the most common symbiont associated with this aphid (Guidolin and Cônsoli, 2018).

Therefore, considering the possible aphid host phenotypes that may arise from interactions with Spiroplasma, we speculated if Spiroplasma infection would result in any fitness costs to the aphid A. citricidus, and if it would influence host plant use by assessing several aphid fitness traits on a highly suitable host plant (Citrus sinensis) as compared to a less suitable host plant (Murraya paniculata) (Guidolin, 2016).

\section{Material and Methods}

\subsection{Aphid isolines}

Adult aphids were collected on unmanaged Citrus sp. groves and on Murraya paniculata in different localities within the municipality of Piracicaba, SP, Brazil. Aphids were brought to the laboratory and classified following the key for wingless adults provided by (Halbert and Brown, 1996).

After species identification, specimens of Aphis citricidus were individually placed on Citrus sinensis seedlings inside rearing cages $(50 \mathrm{~cm}$ high $\times 15 \mathrm{~cm}$ diameter) containing two lateral openings closed with cloth for ventilation. Cages were maintained under controlled conditions $\left(25 \pm 2{ }^{\circ} \mathrm{C}\right.$; $60 \pm 10 \% \mathrm{UR} ; 14 \mathrm{~h}$ photophase) for aphid reproduction and development. Isolines that produced second generation were used for symbiont screening by diagnostic PCR to detect the six most common secondary symbionts associated with aphids, as well as the primary symbiont Buchnera aphidicola and the APSE-1 bacteriophage. We used positive and negative controls for all diagnostics PCR that followed protocols establish by Sandström et al. (2001), Tsuchida et al. (2002) and Oliver et al. (2005). All isolines identified carrying Spiroplasma were also infected by another secondary symbiont. Therefore, an isoline carrying only Buchnera was selected and infected with Spiroplasma donated by a laboratory-established isoline of Aphis aurantii.

\subsection{Artificial infection of A. citricidus with Spiroplasma by microinjection}

An isoline of $A$. citricidus carrying only the obligate symbiont Buchnera aphidicola was selected for the establishment of a sister isoline infected with Spiroplasma for comparative 
analysis of fitness traits between Spiroplasma-infected (Ac-BS) and Spiroplasma-free (Ac-B) sister lines and assessment of fitness costs. Assessments of fitness traits were done on two host plants. Spiroplasma was obtained from a donor isoline of $A$. aurantii, exclusively infected with this secondary symbiont.

The Spiroplasma-free isoline of $A$. citricidus was divided into two groups, and third instars of one of these groups were microinjected with hemolymph collected from the Spiroplasma-infected $A$. aurantii isoline to originate the Spiroplasma-infected sister isoline (Ac-BS). Third instars of the remaining group of $A$. citricidus were microinjected with PBS buffer (137 mM NaCl, $2.7 \mathrm{mM} \mathrm{KCl,} 10 \mathrm{mM}$ $\mathrm{Na}_{2} \mathrm{HPO}_{4}, 2 \mathrm{mM} \mathrm{KH}_{2} \mathrm{PO}_{4}$ ) as control, for the establishment of the so-called Spiroplasma-free isoline (Ac-B).

Microinjections were performed with ultra-thin needles made from borosilicate glass capillary tubes ( $1 \mathrm{~mm}$ e.d. $\mathrm{x}$ 0.78 i.d. - cat\# BF100-78-10, Sutter Instrument Company). The borosilicate glass capillary tubes were shaped into glass needles using a P-1000 Flaming/Brow Micropipette Puller (Sutter Instruments Inc.) with heat set to $550^{\circ} \mathrm{C}$, pull at $60 \mathrm{U}$, velocity at $60 \mathrm{~s}$, pressure at $500 \mathrm{U}$, and time at $250 \mathrm{U}$. Needles were sharpened using a 1300M Beveler (World Precision Instruments Inc.) for $30 \mathrm{~s}$ under $45^{\circ}$. Injections were carried by coupling the needles to a PV830 Pneumatic Pico Pump (World Precision Instruments Inc.) connected to a nitrogen cylinder. Hemolymph was collected using a glass needle after removal of a leg of Spiroplasma-infected $A$. aurantii adults. The same needle was immediately used to microinject a third instar Spiroplasma-free A. citricidus.
Injections were made on the lateral side of the abdomen of A. citricidus. Hemolymph collected from one A. aurantii adult was injected into a single third instar of $A$. citricidus. The needle was replaced after every three injections.

Newly-injected third instars of $A$. citricidus (Ac-BS and $\mathrm{Ac}-\mathrm{B}$ ) were maintained under controlled conditions $\left(25 \pm 2{ }^{\circ} \mathrm{C} ; 60 \pm 10 \% \mathrm{UR} ; 14: 10 \mathrm{~h}\right)$ on Citrus sinensis var. Pêra (sweet orange) as a host plant until they completed their development. Adults obtained from these plants were transferred to Citrus limonia (rangpur) for several generations before their use in further experiments. Nymphs from Ac-B and Ac-BS isolines on rangpur were sampled, subjected to DNA extraction and diagnostic PCR for confirmation of the infection status by Spiroplasma. DNA extraction and diagnostic PCR confirmation of Spiroplasma infection were performed as earlier described (Guidolin and Cônsoli, 2018). Infection status by Spiroplasma was confirmed twice, on the first generation after microinjection to prove that Spiroplasma injected could pass to the next generation, and before estabelish the comparative biology experiments to assure isolines were still positives for Spiroplasma.

\subsection{Biology of Aphis citricidus Ac-BS and Ac-B isolines on sweet orange and orange jasmine}

Spiroplasma-infected (Ac-BS) and Spiroplasma-free (Ac-B) isolines of A. citricidus maintained on rangpur were transferred to orange jasmine (M. paniculata) and sweet orange ( $C$. sinensis var. Pêra). They were reared on these host plants for six generations before biological observations were made (see Figure 1).

\section{Isolines \\ Host plant \\ Development time and survivorship \\ Reproduction and longevity}
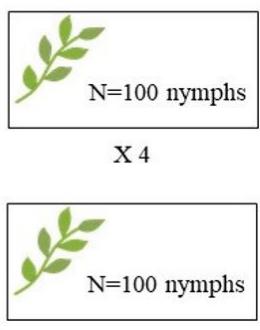

$\mathrm{X} 4$

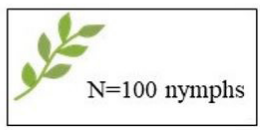

X 4

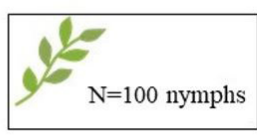

$\mathrm{X} 4$
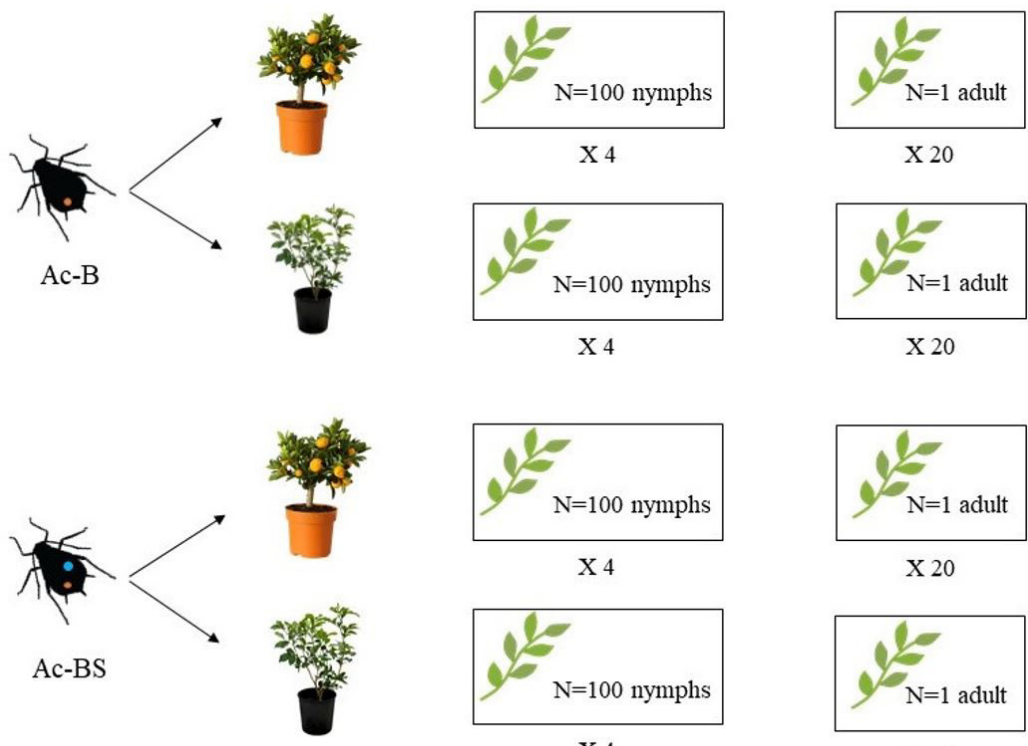

$\mathrm{X} 20$

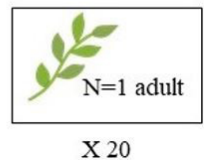

Figure 1. Experimental design for the comparative biology of Aphis citricidus Ac-BS and Ac-B isolines on sweet orange and orange jasmine. 
Plastic cups $(9.5 \times 7.5 \mathrm{~cm})$ containing a ventilation hole at the bottom closed with cloth were used as rearing cages to isolate aphids in new flushes of each host plant to allow for the observation of their development. One-hundred nymphs (0-24h-old) were placed in a new flush within each rearing cage in each one of the host plants studied (orange jasmine or sweet orange), and their time to adult development and survivorship were recorded. Four replicates were made for each isoline in each host plant, with each 100 nymphs as an experimental unit.

For observation of adult reproduction and longevity, 20 newly-emerged adults from each isoline in each one of the host plants were individually caged on a new host plant similar to the host plant they fed as nymphs. Female fecundity and longevity were recorded daily by counting and removing new nymphs until the adult female died.

All colony maintenance and experiments were conducted under controlled conditions $\left(25 \pm 2{ }^{\circ} \mathrm{C} ; 60 \pm 10 \% \mathrm{RH}\right.$; $14 \mathrm{~h}$ photophase).

\subsection{Statistical analysis}

Data normal distribution was checked with Shapiro test and homocedasticity with Bartlett test. To attend normal distribution, data on adult fecundity and longevity on sweet orange were transformed with boxcox algorithm $\lambda=0.4$. The effect of Spiroplasma infection on the biological parameters observed for $A$. citricidus within each host plant was compared using $t$ test $(p<0.05)$. All statistical analyses were carried using the R Statistical software (v.3.2.1; R CORE TEAM, 2015).

The biological data obtained for Ac-BS and Ac-B isolines of A. citricidus in each one of the host plants were also used to estimate life table parameters, such as the net reproductive rate (Ro), the intrinsic rate of increase $(\mathrm{Rm})$, and the finite growth rate $(\lambda)$. Life table parameters were compared by using a paired $t$ test $(p<0.05)$ based on Jackknife estimates using SAS ${ }^{\circledR}$ (SAS Institute, 2015; Maia and Luiz, 2006).

\section{Results}

Spiroplasma had no effect on most of the biological parameters of $A$. citricidus studied regardless the host plant (sweet orange or orange jasmine) (Table 1). Nymph development time was the only parameter affected by Spiroplasma infection, leading to a small delay in immature development in infected aphids when reared on sweet orange (Table 1).

Likewise, life table parameters between Ac-BS and Ac-B isolines of $A$. citricidus were similar within each host plant (Table 2). However, values obtained for $A$. citricidus on sweet orange, regardless of Spiroplasma infection, indicated sweet orange as a much better host to A. citricidus than orange jasmine, as aphids took much longer to double their population and had much lower finite growth rates in orange jasmine if compared to sweet orange (Table 2).

\section{Discussion}

We demonstrated Spiroplasma induced subtle changes on the fitness traits assessed for A. citricidus, independently of the host plant tested. Nymph development time on sweet orange was the only trait to be marginally affected by Spiroplasma, with infected aphids experiencing slower growth. The lack of any significant effects on the aphid fitness traits under the ecological conditions tested coupled with the frequency of occurrence we detected this symbiont in natural populations of $A$. citricidus and $A$. aurantii at the same ecological niche (Guidolin and Cônsoli, 2018), suggest an efficient mechanism for vertical transmission of Spiroplasma and its adaptation to A. citricidus as a host.

Vertical transmission occurs through maternal germlines, and usually maternally-inherited symbionts must benefit

Table 1. Nymph development time and survivorship, percentage of reproductive females and adult longevity and fecundity of Spiroplasma-free (Ac-B) and Spiroplasma-infected A. citricidus (Ac-BS) isolines reared on sweet orange and orange jasmine as host plants $\left(25 \pm 2^{\circ} \mathrm{C} ; 60 \pm 10 \% \mathrm{RH} ; 14 \mathrm{~h}\right.$ photophase) (Mean $\left.\pm \mathrm{SD}\right)$.

\begin{tabular}{|c|c|c|c|c|c|}
\hline Treatment & Ac-B & Ac-BS & $\begin{array}{c}\text { Statistical } \\
\text { test }\end{array}$ & $d f$ & $p$ \\
\hline \multicolumn{6}{|l|}{ Sweet Orange } \\
\hline Nymph development time (days) & $6.1 \pm 0.06 \mathrm{~b}$ & $6.5 \pm 0.09 \mathrm{a}$ & $t=-3.2$ & $(5,5)$ & $<0.05$ \\
\hline Nymph survivorship (\%) & $83.7 \pm 2.59 \mathrm{a}$ & $88.2 \pm 4.97 \mathrm{a}$ & $t=-0.8$ & $(4,5)$ & 0.46 \\
\hline Reproductive female (\%) & $95 \mathrm{a}$ & $95 \mathrm{a}$ & $x^{2}=0$ & $(1)$ & 1 \\
\hline Adult longevity (days) & $8.8 \pm 1.16 \mathrm{a}$ & $7.2 \pm 1.39 \mathrm{a}$ & $t=1.1$ & $(34,7)$ & 0.26 \\
\hline Adult fecundity $\left(\mathrm{N}^{\mathrm{o}}\right.$ nymph/ $\left./+\right)$ & $20.1 \pm 2.57 \mathrm{a}$ & $23.6 \pm 4.97 \mathrm{a}$ & $t=-0.07$ & $(30,5)$ & 0.94 \\
\hline \multicolumn{6}{|l|}{ Orange jasmine } \\
\hline Nymph development time (days) & $6.5 \pm 0.23 \mathrm{a}$ & $6.5 \pm 0.18 \mathrm{a}$ & $t=-0.2$ & $(5,6)$ & 0.86 \\
\hline Nymph survivorship (\%) & $69.5 \pm 3.66 \mathrm{a}$ & $72.7 \pm 3.06 \mathrm{a}$ & $t=-0.68$ & $(5,8)$ & 0.52 \\
\hline Reproductive female (\%) & $90 \mathrm{a}$ & $85 \mathrm{a}$ & $\chi^{2}=0.29$ & (1) & 0.58 \\
\hline Adult longevity (days) & $10.0 \pm 1.83 \mathrm{a}$ & $8.7 \pm 1.7 \mathrm{a}$ & $t=0.2$ & $(32,9)$ & 0.79 \\
\hline Adult fecundity $\left(\mathrm{N}^{\circ}\right.$ nymph/ $\left./+\right)$ & $23.1 \pm 4.34 \mathrm{a}$ & $20.9 \pm 4.63 \mathrm{a}$ & $t=0.15$ & $(32,9)$ & 0.87 \\
\hline
\end{tabular}

Means with the same letter in line are not significantly different at $p>0.05$ using t-test. 
Table 2. Finite growth rate $(\lambda)$, intrinsic rate of increase $(\mathrm{rm})$ and net reproductive rate $(\mathrm{Ro})$ of Spiroplasma-free (Ac-B) and Spiroplasma-infected (Ac-BS) isolines of Aphis citricidus reared on sweet orange and orange jasmine as host plants $\left(25 \pm 2^{\circ} \mathrm{C} ; 60 \pm 10 \% \mathrm{RH} ; 14 \mathrm{~h}\right.$ photophase $)$ $($ Mean $\pm \mathrm{SD})$.

\begin{tabular}{crr}
\hline Treatment & \multicolumn{1}{c}{ Ac-B } & \multicolumn{1}{c}{ Ac-BS } \\
\hline Sweet Orange & & \\
$\lambda$ & $2.4 \pm 0.16 \mathrm{a}$ & $2.6 \pm 0.49 \mathrm{a}$ \\
$r m$ & $0.8 \pm 0.06 \mathrm{a}$ & $0.9 \pm 0.16 \mathrm{a}$ \\
Ro & $16.6 \pm 2.13 \mathrm{a}$ & $20.8 \pm 4.37 \mathrm{a}$ \\
Orange jasmine & & \\
$\lambda$ & $1.9 \pm 0.07 \mathrm{a}$ & $1.9 \pm 0.19 \mathrm{a}$ \\
$r m$ & $0.6 \pm 0.04 \mathrm{a}$ & $0.6 \pm 0.09 \mathrm{a}$ \\
$R o$ & $15.9 \pm 2.99 \mathrm{a}$ & $15.0 \pm 3.33 \mathrm{a}$ \\
\hline
\end{tabular}

Means with the same letter in line are not significantly different at $p>0.05$ using t-test with Jacknife replicates.

their host fitness to guarantee their maintenance and spread in the host population. Reproductive parasites usually benefit the reproductive fitness of infected females by either rendering uninfected females infertile when mating infected males (cytoplasmic incompatibility), favoring female-biased sex ratio in infected females, providing increased resistance against diseases, and adding little fitness cost to the associated host (Stouthamer et al., 1999; Duron et al., 2008; Engelstädter and Hurst, 2009; Jaenike et al., 2010). However, secondary symbionts other than reproductive parasites that are also vertically transmitted must establish relationships in which infected hosts will gain fitness benefits over uninfected hosts to guarantee their persistence in the host population (Oliver et al., 2005; Russell and Moran, 2006; Oliver et al., 2008). It is very unlikely that Spiroplasma assumes a role of a reproductive parasite in A. citricidus, since reproduction of this species in tropical areas is exclusively by telytokous parthenogenesis.

Moreover, benefits to the host and persistence of the interaction will depend on the evolutionary history of the host-symbiont. In the case of aphids, most of the facultative associated symbionts share recent evolutionary histories with their hosts as the benefits symbionts provide to their hosts are highly influenced by several biotic and abiotic conditions (Ferrari et al., 2007; Oliver et al., 2008; 2010; Łukasik et al., 2013a; Cass et al., 2016). Yet, there is a cost associated to harbor one or more secondary symbiont, and persistence and spread of a new infection in a host population depends on the trade-offs between the costs of the maintenance of the symbiont and the benefits the symbiont provide to the host (Oliver et al., 2014; Dykstra et al., 2014; Cayetano et al., 2015).

The lack of fitness costs in the association of $A$. citricidus - Spiroplasma demonstrates that the transfection of a Spiroplasma strain originally infecting A. aurantii into A. citricidus indicates the horizontal transmission of this symbiont may be a natural event in the field where these populations co-occur. Such natural transmission of Spiroplasma between these aphid species would be possible because species co-occur in the same host plants and are attacked by the same natural enemies, where both of these conditions are required for natural horizontal transmission to occur (Duron et al., 2008). The absence of fitness costs in transfected A. citricidus and the fast establishement and maintenance of the infection status in laboratory conditions are also indicatives the Spiroplasma line transferred to A. citricidus was well-adapted to the host immune system (Schmid-Hempel, 2005; Bright and Bulgheresi, 2010).

The successful establishment of an infection by Spiroplasma in A. citricidus and the persistent association through vertical transmission could be associated with the fact that $A$. citricidus and $A$. aurantii share similar ecology and provide a similar physiological environment to Spiroplasma. Interspecific transfections were highly successful when species shared similar physiological enviroments and ecology (Perlman and Jaenike, 2003; Longdon et al., 2011; Łukasik et al., 2013b).

We have to consider that the neutral outcome of the interaction between Spiroplasma and A. citricidus may be due to the fact infected aphids were not exposed to a selection pressure, such as a fungal pathogen and/or an abiotic stress condition, in which the costs of infection to the host could be perceived, as often observed for infected aphids under some stress conditions (Oliver et al., 2008). We understand our data imposes limitations in making broad conclusions as we observed the effects of Spiroplasma on a single genetic pool. On the other hand, the experimental set up used allowed us to isolate noise coming from the interactions of different genotypes with Spiroplasma, allowing us to conduct our analysis without interference of host genetic variability.

In conclusion, Spiroplasma infection did not yield any fitness cost to $A$. citricidus as no changes in the assessed fitness traits were observed in response to the nutritional quality of the host plant. However, comparative proteomic analysis of Spiroplasma-infected and healthy aphids on host plants with different nutritional value to the aphid indicated Spiroplasma may have a strong influence on the host nutritional immunity (Guidolin et al., 2018). Therefore, the phenotype induced by Spiroplasma infection of $A$. citricidus remains to be determined and will require further investigations under different selection pressures, such as those that challenge the host immune system.

\section{Acknowledgements}

Authors thank FAPESP by providing a $\mathrm{PhD}$ fellowship to ASG (Grant \# 2012/04287-0, São Paulo Research Foundation). Authors also thank CNPq (Grant \# 490474/2011-0) and FAPESP (Grant \# 2011/50877-0, São Paulo Research Foundation) for providing research funds to the senior author FLC.

\section{Reference}

ANBUTSU, H. and FUKATSU, T., 2011. Spiroplasma as a model insect endosymbiont. Environmental Microbiology Reports, vol. 3, no. 2, pp. 144-153. http://dx.doi.org/10.1111/j.17582229.2010.00240.x. PMid:23761245. 
AUGUSTINOS, A.A., SANTOS-GARCIA, D., DIONYSSOPOULOU, E., MOREIRA, M., PAPAPANAGIOTOU, A., SCARVELAKIS, M., DOUDOUMIS, V., RAMOS, S., AGUIAR, A.F., BORGES, P.A.V., KHADEM, M., LATORRE, A., TSIAMIS, G. and BOURTZIS, K., 2011. Detection and characterization of Wolbachia infections in natural populations of aphids:is the hidden diversity fully unraveled? PLoS One, vol. 6, no. 12, pp. e28695. http://dx.doi.org/10.1371/journal. pone.0028695. PMid:22174869.

BOURTZIS, K. and MILLER, T.A., 2006. Insect symbiosis. Vol. 2. Boca Raton: CRC Press. 304 p.

BRADY, C.M. and WHITE, J.A., 2013. Cowpea aphid (Aphis craccivora) associated with different host plants has different facultative endosymbionts. Ecological Entomology, vol. 38, no. 4, pp. 433-437. http://dx.doi.org/10.1111/een.12020.

BRADY, C.M., ASPLEN, M.K., DESNEUX, N., HEIMPEL, G.E., HOPPER, K.R., LINNEN, C.R., OLIVER, K.M., WULFF, J.A. and WHITE, J.A., 2014. Worldwide populations of the aphid Aphis craccivora are infected with diverse facultative bacterial symbionts. Microbial Ecology, vol. 67, no. 1, pp. 195-204. http:// dx.doi.org/10.1007/s00248-013-0314-0. PMid:24233285.

BRIGHT, M. and BULGHERESI, S., 2010. A complex journey: transmission of microbial symbionts. Nature Reviews. Microbiology, vol. 8, no. 3, pp. 218-230. http://dx.doi.org/10.1038/nrmicro2262. PMid:20157340.

BUCHNER, P., 1965. Endosymbiosis of animals with plant microorganisms. New Jersey: Interscience Publishers/John Wiley. 909 p.

BURKE, G.R. and MORAN, N.A., 2011. Responses of the pea aphid transcriptome to infection by facultative symbionts. Insect Molecular Biology, vol. 20, no. 3, pp. 357-365. http://dx.doi. org/10.1111/j.1365-2583.2011.01070.x. PMid:21382108.

CASS, B.N., HIMLER, A.G., BONDY, E.C., BERGEN, J.E., FUNG, S.K., KELLY, S.E. and HUNTER, M.S., 2016. Conditional fitness benefits of the Rickettsia bacterial symbiont in an insect pest. Oecologia, vol. 180, no. 1, pp. 169-179. http:// dx.doi.org/10.1007/s00442-015-3436-x. PMid:26376661.

CAYETANO, L., ROTHACHER, L., SIMON, J.C. and VORBURGER, C., 2015. Cheaper is not always worse: strongly protective isolates of a defensive symbiont are less costly to the aphid host. Proceedings of the Royal Society B-Biological Sciences, vol. 282, no. 1799, pp. 20142333.

DOUGLAS, A.E., 1998. Nutritional interactions in insect-microbial symbioses: aphids and their symbiotic bacteria Buchnera. Annual Review of Entomology, vol. 43, no. 1, pp. 17-37. http://dx.doi. org/10.1146/annurev.ento.43.1.17. PMid:15012383.

DURON, O., BOUCHON, D., BOUTIN, S., BELLAMY, L., ZHOU, L., ENGELSTÄDTER, J. and HURST, G.D., 2008. The diversity of reproductive parasites among arthropods: Wolbachia do not walk alone. BMC Biology, vol. 6, pp. 27. http://dx.doi. org/10.1186/1741-7007-6-27. PMid:18577218.

DYKSTRA, H.R., WELDON, S.R., MARTINEZ, A.J., WHITE, J.A., HOPPER, K.R., HEIMPEL, G.E., ASPLEN, M.K. and OLIVER, K.M., 2014. Factors limiting the spread of the protective symbiont Hamiltonella defensa in Aphis craccivora aphids. Applied and Environmental Microbiology, vol. 80, no. 18 , pp. 5818-5827. http://dx.doi.org/10.1128/AEM.01775-14. PMid:25015890.
EBBERT, M.A., 1991. The interaction phenotype in the Drosophia willistoni-Spiroplasma symbiosis. Evolution; International Journal of Organic Evolution, vol. 45, no. 4, pp. 971-988. PMid:28564045.

ENGELSTÄDTER, J. and HURST, G.D.D., 2009. The ecology and evolution of microbes that manipulate host reproduction. Annual Review of Ecology Evolution and Systematics, vol. 40, no. 1, pp. 127-149. http://dx.doi.org/10.1146/annurev.ecolsys.110308.120206.

FERRARI, J., MÜLLER, C.B., KRAAIJEVELD, A.R. and GODFRAY, H., 2001. Clonal variation and covariation in aphid resistance to parasitoids and a pathogen. Evolution; International Journal of Organic Evolution, vol. 55, no. 9, pp. 1805-1814. http:// dx.doi.org/10.1111/j.0014-3820.2001.tb00829.x. PMid:11681735.

FERRARI, J., SCARBOROUGH, C.L. and GODFRAY, H.C.J., 2007. Genetic variation in the effect of a facultative symbiont on host-plant use by pea aphids. Oecology, vol. 153, no. 2, pp. 323-329. http://dx.doi.org/10.1007/s00442-007-0730-2. PMid:17415589.

FERRARI, J., WEST, J.A., VIA, S. and GODFRAY, H., 2012. Population genetic structure and secondary symbionts in hostassociated populations of the pea aphid complex. Evolution, vol. 66, no. 2, pp. 375-390. http://dx.doi.org/10.1111/j.15585646.2011.01436.x. PMid:22276535.

FORISTER, M.L., NOVOTNY, V., PANORSKA, A.K., BAJE, L., BASSET, Y., BUTTERILL, P.T., CIZEK, L., COLEY, P.D., DEM, F., DINIZ, I.R., DROZD, P., FOX, M., GLASSMIRE, A.E., HAZEN, R., HRCEK, J., JAHNER, J.P., KAMAN, O., KOZUBOWSKI, T.J., KURSAR, T.A., LEWIS, O.T., LILL, J., MARQUIS, R.J., MILLER, S.E., MORAIS, H.C., MURAKAMI, M., NICKEL, H., PARDIKES, N.A., RICKLEFS, R.E., SINGER, M.S., SMILANICH, A.M., STIREMAN, J.O., VILLAMARÍN-CORTEZ, S., VODKA, S., VOLF, M., WAGNER, D.L., WALLA, T., WEIBLEN, G.D. and DYER, L.A., 2015. The global distribution of diet breadth in insect herbivores. Proceedings of the National Academy of Sciences of the United States of America, vol. 112, no. 2, pp. 442-447. http:// dx.doi.org/10.1073/pnas.1423042112. PMid:25548168

FUKATSU, T., TSUCHIDA, T., NIKOH, N. and KOGA, R., 2001. Spiroplasma symbiont of the pea aphid, Acyrthosiphon pisum (Insecta: Homoptera). Applied and Environmental Microbiology, vol. 67, no. 3, pp. 1284-1291. http://dx.doi.org/10.1128/ AEM.67.3.1284-1291.2001. PMid:11229923.

GASPARICH, G.E., 2002. Spiroplasmas: evolution, adaptation and diversity. Frontiers in Bioscience, vol. 7, pp. 619-640. PMid:11861210.

GUIDOLIN, A.S. and CÔNSOLI, F.L., 2018. Diversity of the most commonly reported facultative symbionts in two closely-related aphids with different host ranges. Neotropical Entomology, vol. 47, no. 4, pp. 440-446. http://dx.doi.org/10.1007/s13744-0170532-0. PMid:28620748.

GUIDOLIN, A.S., 2016. Multipartite interactions of Aphis (Toxoptera) and their associated symbionts. University of Sao Paulo, 310 p. PhD Thesis Dissertation.

GUIDOLIN, A.S., CATALDI, T.R., LABATE, C.A., FRANCIS, F. and CÔNSOLI, F.L., 2018. Spiroplasma affects host aphid proteomics feeding on two nutritional resources. Scientific Reports, vol. 8, no. 1, pp. 2466. http://dx.doi.org/10.1038/s41598-01820497-9. PMid:29410456.

HALBERT, S.E. and BROWN, L.G., 1996. Toxoptera citricida (Kirkaldy), brown citrus aphid - identification, biology and management strategies. Florida Department of Agriculture 
and Consumer Services Division of Plant Industry Entomology Circular, Gainesville, vol. 374, pp. 6.

HALBERT, S.E., GENC, H., CEVIK, B., BROWN, L.G., ROSALES, I.M., MANJUNATH, K.L., POMERINKE, M., DAVISON, D.A., LEE, R.F. and NIBLETT, C.L., 2004. Distribution and characterization of Citrus tristeza virus in South Florida following establishment of Toxoptera citricida. Plant Disease, vol. 88, no. 9, pp. 935-941. http://dx.doi.org/10.1094/ PDIS.2004.88.9.935. PMid:30812245.

HANSEN, A.K. and MORAN, N.A., 2014. The impact of microbial symbionts on host plant utilization by herbivorous insects. Molecular Ecology, vol. 23, no. 6, pp. 1473-1496. http:// dx.doi.org/10.1111/mec.12421. PMid:23952067.

HEYWORTH, E.R. and FERRARI, J., 2015. A facultative endosymbiont in aphids can provide diverse ecological benefits. Journal of Evolutionary Biology, vol. 28, no. 10, pp. 1753-1760. http://dx.doi.org/10.1111/jeb.12705. PMid:26206380.

JAENIKE, J., UNCKLESS, R., COCKBURN, S.N., BOELIO, L.M. and PERLMAN, S.J., 2010. Adaptation via symbiosis: recent spread of a Drosophila defensive symbiont. Science, vol. 329, no. 5988, pp. 212-215. http://dx.doi.org/10.1126/science.1188235. PMid:20616278.

LEONARDO, T.E. and MUIRU, G.T., 2003. Facultative symbionts are associated with host plant specialization in pea aphid populations. Proceedings. Biological Sciences, vol. 270, suppl. 2, pp. 209-212. http://dx.doi.org/10.1098/rsbl.2003.0064. PMid:14667385.

LONGDON, B., HADFIELD, J.D., WEBSTER, C.L., OBBARD, D.J. and JIGGINS, F.M., 2011. Host phylogeny determines viral persistence and replication in novel hosts. PLoS Pathogens, vol. 7, no. 9, pp. e1002260. http://dx.doi.org/10.1371/journal. ppat.1002260. PMid:21966271.

ŁUKASIK, P., DAWID, M.A., FERRARI, J. and GODFRAY, H.C., 2013a. The diversity and fitness effects of infection with facultative endosymbionts in the grain aphid, Sitobion avenae. Oecologia, vol. 173, no. 3, pp. 985-996. http://dx.doi.org/10.1007/ s00442-013-2660-5. PMid:23624672.

ŁUKASIK, P., GUO, H., VAN ASCH, M., FERRARI, J. and GODFRAY, H.C., 2013b. Protection against a fungal pathogen conferred by the aphid facultative endosymbionts Rickettsia and Spiroplasma is expressed in multiple host genotypes and species and is not influenced by co-infection with another symbiont. Journal of Evolutionary Biology, vol. 26, no. 12, pp. 2654-2661. http://dx.doi.org/10.1111/jeb.12260. PMid:24118386.

ŁUKASIK, P., VAN ASCH, M., GUO, H., FERRARI, J. and GODFRAY, H.C., 2012. Unrelated facultative endosymbionts protect aphids against a fungal pathogen. Ecology Letters, vol. 16, no. 2, pp. 214-218. http://dx.doi.org/10.1111/ele.12031. PMid:23137173.

MAIA, A.D.H.N. and LUIZ, A.J.B., 2006. Programa SAS para análise de tabelas de vida e fertilidade de artrópodes: o método Jackknife. EMBRAPA, vol. 33, pp. 1-11.

MCLEAN, A.H., VAN ASCH, M., FERRARI, J. and GODFRAY, H.C., 2011. Effects of bacterial secondary symbionts on host plant use in pea aphids. Proceedings of the Royal Society B-Biological Sciences, vol. 278, no. 1706, pp. 760-766. http://dx.doi.org/10.1098/ rspb.2010.1654.

MONTLlOR, C.B., MAXMEN, A. and PURCELL, A.H., 2002. Facultative bacterial endosymbionts benefit pea aphids
Acyrthosiphon pisum under heat stress. Ecological Entomology, vol. 27, no. 2, pp. 189-195. http://dx.doi.org/10.1046/j.13652311.2002.00393.x.

MORAN, N.A., 2007. Symbiosis as an adaptive process and source of phenotypic complexity. Proceedings of the National Academy of Sciences of the United States of America, vol. 104, suppl. 1, pp. 8627-8633. http://dx.doi.org/10.1073/pnas.0611659104. PMid:17494762.

MOREIRA, L.A., ITURBE-ORMAETXE, I., JEFFERY, J.A., LU, G., PYKE, A.T., HEDGES, L.M., ROCHA, B.C., HALLMENDELIN, S., DAY, A., RIEGLER, M., HUGO, L.E., JOHNSON, K.N., KAY, B.H., MCGRAW, E.A., VAN DEN HURK, A.F., RYAN, P.A. and O'NEILL, S.L., 2009. Wolbachia symbiont in Aedes aegypti limits infection with Dengue, Chikungunya, and Plasmodium. Cell, vol. 139, no. 7, pp. 1268-1278. http://dx.doi. org/10.1016/j.cell.2009.11.042. PMid:20064373.

OLIVER, K.M., CAMPOS, J., MORAN, N.A. and HUNTER, M.S., 2008. Population dynamics of defensive symbionts in aphids. Proceedings Biological Sciences, vol. 275, no. 1632, pp. 293299. http://dx.doi.org/10.1098/rspb.2007.1192. PMid:18029301.

OLIVER, K.M., DEGNAN, P.H., BURKE, G.R. and MORAN, N.A., 2010. Facultative symbionts in aphids and the horizontal transfer of ecologically important traits. Annual Review of Entomology, vol. 55, no. 1, pp. 247-266. http://dx.doi.org/10.1146/ annurev-ento-112408-085305. PMid:19728837.

OLIVER, K.M., MORAN, N.A. and HUNTER, M.S., 2005. Variation in resistance to parasitism in aphids is due to symbionts not host genotype. Proceedings of the National Academy of Sciences of the United States of America, vol. 102, no. 36, pp. 12795-12800. http://dx.doi.org/10.1073/pnas.0506131102. PMid:16120675.

OLIVER, K.M., SMITH, A.H. and RUSSELL, J.A., 2014. Defensive symbiosis in the real world -advancing ecological studies of heritable, protective bacteria in aphids and beyond. Functional Ecology, vol. 28, no. 2, pp. 341-355. http://dx.doi. org/10.1111/1365-2435.12133.

PERLMAN, S.J. and JAENIKE, J., 2003. Infection success in novel hosts: an experimental and phylogenetic study of Drosophila-parasitic nematodes. Evolution; International Journal of Organic Evolution, vol. 57, no. 3, pp. 544-557. http://dx.doi. org/10.1111/j.0014-3820.2003.tb01546.x. PMid:12703944.

R CORE TEAM, 2015 [viewed 28 May 2018]. R: A language and environment for statistical computing. Vienna: R Forundata on for Statistical Computing. Available from: https://www.R-project.org

RUSSELL, J.A. and MORAN, N.A., 2006. Costs and benefits of symbiont infection in aphids: variation among symbionts and across temperatures. Proceedings. Biological Sciences, vol. 273, no. 1586, pp. 603-610. http://dx.doi.org/10.1098/rspb.2005.3348. PMid:16537132.

RUSSELL, J.A., WELDON, S., SMITH, A.H., KIM, K.L., HU, Y., LUKASIK, P., DOLL, S., ANASTOPOULOS, I., NOVIN, M. and OLIVER, K.M., 2013. Uncovering symbiont driven genetic diversity across North American pea aphids. Molecular Ecology, vol. 22, no. 7, pp. 2045-2059. http://dx.doi.org/10.1111/ mec.12211. PMid:23379399.

SANDSTRÖM, J.P., RUSSELL, J.A., WHITE, J.P. and MORAN, N.A., 2001. Independent origins and horizontal transfer of bacterial symbionts of aphids. Molecular Ecology, vol. 10, no. 1, pp. 217-228. http://dx.doi.org/10.1046/j.1365-294X.2001.01189.x. PMid:11251800. 
SAS INSTITUTE, 2015. SAS language. Version 9. Cary: SAS Institute Inc.

SCHMID-HEMPEL, P., 2005. Evolutionary ecology of insect immune defenses. Annual Review of Entomology, vol. 50, no. 1, pp. 529-551. http://dx.doi.org/10.1146/annurev.ento.50.071803.130420. PMid:15471530.

SIMON, J.C., BOUTIN, S., TSUCHIDA, T., KOGA, R., LE GALLIC, J., FRANTZ, A., OUTREMAN, Y. and FUKATSU, T., 2011. Facultative symbiont infections affect aphid reproduction. PLoS One, vol. 6, no. 7, pp. e21831. http://dx.doi.org/10.1371/ journal.pone.0021831. PMid:21818272.

STOUTHAMER, R., BREEUWER, J.A.J. and HURST, G.D.D., 1999. Wolbachia pipientis: Microbial manipulator of arthropod reproduction. Annual Review of Microbiology, vol. 53, no. 1, pp. 71-102. http://dx.doi.org/10.1146/annurev.micro.53.1.71. PMid:10547686.

SU, Q., ZHOU, X. and ZHANG, Y., 2013. Symbiont-mediated functions in insect hosts. Communicative \& Integrative Biology, vol. 6, no. 3, pp. e23804. http://dx.doi.org/10.4161/cib.23804. PMid:23710278.

SUGIO, A., DUBREUIL, G., GIRON, D. and SIMON, J.C., 2015. Plant-insect interactions under bacterial influence: ecological implications and underlying mechanisms. Journal of Experimental Botany, vol. 66, no. 2, pp. 467-478. http://dx.doi.org/10.1093/jxb/ eru435. PMid:25385767.

TEIXEIRA, L., FERREIRA, A. and ASHBURNER, M., 2008. The bacterial symbiont Wolbachia induces resistance to RNA viral infections in Drosophila melanogaster. PLoS Biology, vol. 6, no. 12, pp. 2753-2763. http://dx.doi.org/10.1371/journal. pbio.1000002. PMid:19222304.

TSUCHIDA, T., KOGA, R. and FUKATSU, T., 2004. Host plant specialization governed by facultative symbiont. Science, vol. 303, no. 5666, pp. 1989-1989. http://dx.doi.org/10.1126/ science.1094611. PMid:15044797.

TSUCHIDA, T., KOGA, R., FUJIWARA, A. and FUKATSU, T., 2014. Phenotypic effect of "Candidatus Rickettsiella viridis," a facultative symbiont of the pea aphid (Acyrthosiphon pisum), and its interaction with a coexisting symbiont. Applied and Environmental Microbiology, vol. 80, no. 2, pp. 525-533. http:// dx.doi.org/10.1128/AEM.03049-13. PMid:24212575.

TSUCHIDA, T., KOGA, R., SHIBAO, H., MATSUMOTO, T. and FUKATSU, T., 2002. Diversity and geographic distribution of secondary endosymbiotic bacteria in natural populations of the pea aphid, Acyrthosiphon pisum. Molecular Ecology, vol. 11, no. 10, pp. 2123-2135. http://dx.doi.org/10.1046/j.1365294X.2002.01606.x. PMid:12296954.

XIE, J., VILCHEZ, I. and MATEOS, M., 2010. Spiroplasma bacteria enhance survival of Drosophila hydei attacked by the parasitic wasp Leptopilina heterotoma. PLoS One, vol. 5, no. 8, pp. e12149. http://dx.doi.org/10.1371/journal.pone.0012149. PMid:20730104

ZYTYNSKA, S.E. and WEISSER, W.W., 2016. The natural occurrence of secondary bacterial symbionts in aphids. Ecological Entomology, vol. 41, no. 1, pp. 13-26. http://dx.doi.org/10.1111/ een.12281. 